logos_i_ethos_2016_(43)_numer_specjalny_2, s. 77-87

DOI: http://dx.doi.org/10.15633/lie.1961

Janna Voskressenskaia

\title{
The Reign and the Freedom. A Controversial Question in Peter Chaadaev's Thought
}

Peter Chaadaev was one of the pioneers of independent philosophical thought in Russia, as well as a sincere Christian and faithful patriot. This extraordinary man left one great les-

Janna Voskressenskaia - PhD student at Università Vita-Salute San Raffaele (Milan), a member of CRISI (Center of Studies on History of Ideas). Main interests: Russian philosophy, metaphysics, philosophy of religion. son to the succeeding Russian philosophical tradition. This was that the value of any human action, as well as that of the entire nation, can only be defined within its relation to the concept of truth. By truth, Chaadaev meant the inescapable belonging of the creatures to the Creator, their destiny as the complete fulfillment of God's design.

In this perspective the authentic aim of history, its telos, is seen as the necessary accomplishment of God's reign. Chaadaev stated that, for a Christian, the development of human spirit through time is nothing but the reflection of God's activity exerted on this world. ${ }^{1}$ Men should submit themselves to God's will in order to reestablish unity with the Creator. For this reason men should deny their supposed freedom, their individual and personal being in order to achieve the social and "impersonal" one. The author maintains that the common concept of freedom is self-deception. A conviction of being able to act against God's design is just a rope of sand. Freedom consists only in having no perception of

1 P. Chaadaev, The Philosophical Letters Addressed to a Lady, in: The Major Works of Peter Chaadaev, transl. R. McNally, Notre Dame 1969, p. 69. 
the constriction. The constriction here means no chance to change the destiny God prepared for His creature.

Based on these premises, the proposed paper intends to analyze Peter Chaadaev's thought starting from his understanding of history. Attention will be paid especially to his view on Christianity fulfillment through time in order to understand the part mankind takes in building God's reign as well as soteriology.

Zenkovsky stated in his A History of Russian Philosophy that Chaadaev gave birth to a theology of culture. ${ }^{2}$ His precious contribution to Russian philosophy is undeniable yet, at the same time, his thought is full of cavils and trials.

Taking into consideration the theoretical grounding of Peter Chaadaev's thought, together with the author's intentions within the scope of philosophy of history, the issue is to show the incoherence of whatever thought willing to give shape to the authentic Christian sense of history without any regard to the concept of person and radical freedom connected to it. Indeed, difficulties arise when Chaadaev tries to define both ethical bases and the value of humans' actions. This author states that good actions cannot be actively exerted by men, for they are nothing but the result of human submission to the invisible power of the Creator. Human creations are somehow underestimated and even the Bible is seen as a mere Church product, a book written by men long ago.

These points are more than mere speculative inconsistencies. If the Bible is a simple report of ideas dictated by God and submitted to human beings centuries ago, then Christian perspective on tradition and a continuous vivid interpretation of Scripture cannot be maintained. Some considerations will be made on this topic, highlighting the importance of the human person and the intimate relationship between men and God.

E. Trubetskoy wrote that the best tribute to a philosopher who has passed away consists in applying to his thought a form of critique that can 2006, p. 169.

2 Cf. V. V. Zenkovsky, A History of Russian Philosophy, vol. 1, transl. G. L. Kline, London 
separate the supratemporal elements of his teaching from temporal ones. This would allow all of the vital seeds of his philosophy to breed, while purifying it from the obsolete shadows that historical events cast upon it. ${ }^{3}$

In fact, all these ambiguities are due to the one basic difficulty corroding Chaadaev's theoretical asset. This difficulty can be summed up as a sacrifice of the particular, the single and the individual, in the name of the universal.

\section{The ineluctable progress}

In his first Philosophical Letter Chaadaev stated that the historical aspect forms the essential part of the dogma, since it reveals what Christianity has done for man and what it can do for him in the future. In this way, he continues, Christian religion is revealed not only as a moral system, conceived in the perishable forms of the human spirit, but as an eternal, divine power, acting universally in the spiritual world, which visible action ought to present us with a perpetual lesson.

Thus, he maintains, in the Christian world everything must necessarily lead towards the establishment of a perfect order on earth and it does contribute to it really, otherwise the word given by God, that is the promise to remain with His Church till the end of times, would be denied by the facts. ${ }^{4}$

So, what is the nature of this visible divine action and the heart of the revelation? The Russian philosopher explains that only the teaching founded upon the supreme principle of unity and the direct transmission of truth in an uninterrupted succession of its ministers can be the one most in accord with the true spirit of religion. The unity he mentions should concern the fusing of all the moral forces upon the earth into a simple thought, a simple sentiment and into the gradual establishment of a social system or Church, which must make truth reign among men ${ }^{5}$.

See Е. Трубецкой, Миросозериание Вл. С. Соловьева, т. 1, Москва 1913, p. IX.

P. Chaadaev, The Philosophical Letters Addressed to a Lady, op. cit., p. 41.

5 P. Chaadaev, The Philosophical Letters Addressed to a Lady, op. cit., p. 25. 
The author continues, stating that every other teaching, distant from this doctrine, wholly rejects the effect of Christ's words: "My Father, I beg you that they may be one as we are one," and does not want God's reign upon earth.

From these few lines we can already see that, for the author, Christian religion concerns a realization of God's Reign upon earth, that is a certain socio-ethical asset, which should be identified with the church. God gave the supreme moral law to the world and is awaiting its complete realization. This would mean the end of history, the great apocalyptic synthesis, ${ }^{6}$ as the author calls it. The moral law given to us means that supreme reason, that is God, ordered us to do unto the others as we would have them do unto us. In other words, the highest commandment, as defined by this author, reminds us of the Kantian imperative: it concerns duties, but tells us nothing about love. Furthermore, even though the author insists on the necessity of practicing the moral law, he still maintains, as we have already seen that the divine action can already be glimpsed through history.

Indeed, Chaadaev notes that in the European states God's reign has somehow been realized because it contains the principle of indefinite progress and possesses elementarily all that is needed for God's reign to become established definitely upon earth one day.

Thus, there is unity to be achieved, there is the means for this task that is the moral law given to humans and there is a relentless spirit, who will peremptorily give life sooner or later to his design upon earth and whose action is already visible in the European history. If so, what is the true human part in all this ineluctable progress? Is the moral law really needed if the universe is destined to reflect God's plans on it independently on human decisions? And is it possible to insist on human responsibility and duties, when it is already known that the end of history has been eternally decided once and for all? 


\section{The anthropological issue by Chaadaev}

We started analyzing Chaadaev's view on history and reached the problem of human freedom. Indeed, if the telos of everything has already been established, a single man seems to be less than a puppet moved by the master. In order to understand the issue, it is necessary to delineate the ontological aspect concerning human existence as theorized by Chaadaev.

Even though the author never clearly defined the nature of personal being, nevertheless there are all the elements in his fundamental Philosophical Letters that allow us to understand the main traits and the difficulties of his theory, when he tries to conceal human responsibility and freedom with God's design upon history.

The author maintains that the nature of a rational being is its consciousness. ${ }^{7}$ As long as men are conscious, they do not lose their nature. The day man was created, the Creator talked to him while man was listening and understanding His words. Chaadaev states that was the very origin of human reason, a feature that can be endlessly illuminated. ${ }^{8}$ Human reason is a constant reproduction of God's thought and even though it became distant from the Creator, it still feels the need of renewal and retrieval. For Russian philosopher, humanity is supposed to become conscious of the connection with the Father of everything existing in order to install the kingdom of truth on the earth. However, this awareness cannot be reached by a single man. For, every man is just a member of the all-embracing world consciousness, acting through centuries. ${ }^{9}$ The latter is the totality of all the ideas living in people's memory. In other words, the world consciousness that we are all part of is tradition. The Creator's reason has been expressed by humans through time.

The author exclaims that happy are those, who have in their hearts the intimate realization of the effects which they produce. Indeed, not all of

\footnotetext{
P. Chaadaev, The Philosophical Letters Addressed to a Lady, op. cit., p. 101.

P. Chaadaev, The Philosophical Letters Addressed to a Lady, op. cit., p. 95-96.

P. Chaadaev, The Philosophical Letters Addressed to a Lady, op. cit., p. 92.
} 
the men are active instruments, not all of them act with awareness: multitude, inanimate atoms, inert masses are moved blindly without recognizing the forces which set them in motion and without perceiving the goal towards which they are driven. ${ }^{10}$ This means that everyone is destined to realize his inescapable part in history and the only difference between men rests in their ability to understand they are moved by a supreme force they cannot resist.

Therefore, Chaadaev says, we should simply try to get the clearest idea possible of its action upon us and surrender ourselves to it with faith and confidence, for this force which acts upon us without our knowledge never errs and it causes the universe to advance towards its destiny. ${ }^{11}$

After a brief analysis of the principle traits of Chaadaev's thought, it is necessary to make some critical notes in order to show how his perspective, even though it still remains fundamental within the history of Russian philosophy, cannot be properly called Christian. The main issues to be pointed out regard the concept of the human being and the freedom.

If freedom never transcends the divine action, If it belongs only to God, and can only be participated in by men, then human freedom can only be reduced to a pure reproduction, it becomes mere submission to the divine will. Does this picture reflect the authentic Christian thought on the status of the creature and the issue of free will?

St. Maximus the Confessor states that man is a Godly creature by his nature and at the same time a son of God by the act of grace. The theologian explains in his commentary to Gregory of Nazianzus that it would not be possible for a created man to appear as a son of God, if not being born in Spirit by his own conscious decision. And this decision has its origin in the same potential for the movement man was originally given by nature. That is, man was born in freedom and can find the source of his action in his own self (Ambigua, PG 42, 1345D).

10 P. Chaadaev, The Philosophical Letters Addressed to a Lady, op. cit., p. 49.

11 P. Chaadaev, The Philosophical Letters Addressed to a Lady, op. cit., p. 75. 
Chaadaev actually mentions that men are constantly making arbitrary movements, shaking the entire universe. ${ }^{12}$ This statement can be interpreted as an admission of a concrete and active human freedom, able to escape from the Creator's control, but it remains an isolated phrase, probably dictated by the need to denote the evil caused by human action, the issue that Chaadaev suffered profoundly, especially in relationship with his own country's social troubles and backwardness. Unfortunately, the Russian philosopher leaves apart whatever consideration of human being as person endowed with free will and grounds all his theory on the basis of the self-revealing reason, guiding the world and the mankind as well.

The culmination of Chaadaev's theory, neglecting the urge for a definition of human freedom, can be definitely found in the VIII Letter, the closing and the summarizing one. Here, the author explains that the progression towards God's reign is due to the participation of human reason in the divine, thus, every spiritual attainment made by humans is just a step towards the supreme end, a step that should necessarily be overpassed in view of apocalyptic kingdom. Even the Bible and dogma should be inscribed within this perspective. Chaadaev writes:

As is known, Christianity was consolidated without the cooperation of any kind of book. In the second century Christianity had already conquered the world. And from that time onward the human race was subjected irrevocably to it. People imagine that they only have to disseminate this book throughout the earth in order to convert the world! A wretched idea on which the apostates passionately subsist!

It is in men made such as we, made as He was, that divine reason lives on, not in the volume fabricated by the Church. And that is precisely why the obstinate attachment on the part of traditional people to the astounding dogma of the real presence of the body in the Eucharist and this hyperbolic worship of the body of the Savior are so admirable. Nothing helps us understand the source of Christian truth better than that: nothing helps us see more clearly the necessity of striving to realize the material presence of the God-man among us in every possible way, by evoking his

12 P. Chaadaev, The Philosophical Letters Addressed to a Lady, op. cit., p. 103. 
corporeal image continually before our eyes as the eternal model and lesson for the new humanity. ${ }^{13}$

This consideration cannot be held together with the Christian perception of the Scripture, especially today with the one which emerged from the Second Vatican Council. One of the issues of Dei Verbum, indeed, considers the relationship between men, both as writers and readers, and the Bible: "God chose men and while employed by Him they made use of their powers and abilities, so that with Him acting in them and through them, they, as true authors, consigned to writing everything and only those thing He wanted." ${ }^{14}$ But

since the Holy Scripture must be read and interpreted in the sacred spirit in which it was written, no less serious attention must be given to the content and unity of the whole Scripture if the meaning of the sacred texts is to be correctly worked out. The living tradition of the whole Church must be taken into account along with harmony which exists between elements of the faith. ${ }^{15}$

Today it became clearer that the Scripture should be read and studied, should be considered as a living tradition, where the authors, free persons chosen by God for cooperation, address God's word to the other free persons, reading their words. ${ }^{16}$ Dialogue is a proper dimension for the Bible reading, for it is not a fossil witnessing a bygone fact of revelation, but the arena for the encounter of personal freedoms (as the same person of Christ allows the encounter between two radically different wills).

Chaadaev's perspective appears contradictory: on one hand men can shake the universe and even write a book revealing a concrete contact between the authors and God while on the other hand the philosopher

13 P. Chaadaev, The Philosophical Letters Addressed to a Lady, op. cit., p. 195-196.

14 Second Vatican Council, Dogmatic Constitution on Divine Revelation Dei Verbum, III, 11, http://www.vatican.va/archive/hist_councils/ii_vatican_council/documents/vat-ii_const_19651118_ dei-verbum_en.html.

15 Second Vatican Council, Dogmatic Constitution on Divine Revelation Dei Verbum, III, 12.

16 See P. Beauchamp, Parler d'Ecritures Saintes, Paris 1987. 
does not consider the vivid relation between persons as radically free actors. Personhood is never able to acquire an absolute value in his theory, mostly based on the idea of the progressive self-revelation of the spirit, so close in that to the German philosophy he was widely acquainted and identified with.

The main issue that obscures Chaadaev's thought in becoming authentically Christian is the lack of the clear and strong concept of the human being as person and hypostasis. This is the reason he can describe masses as inert and unconscious beings, dragged by superior forces towards the end of history. Identifying human nature with pure consciousness, he first of all somehow denies existence to all those people, who never exert it actively. Indeed, Chaadaev calls them "inanimate atoms."

Two difficulties emerge from this strong consideration. The first one regards the possibility of building the same perfect community that the author longs for: if men can realize their nature, identified with consciousness, only by communication with other conscious men, how then would it be possible for humans to exert their own nature, if they are mostly surrounded by inert masses which are mechanically following the divine will? Chaadaev somehow answers this question in his VII Letter: there are some single personalities who can guide the whole of humanity. Even though Christian thought definitely admits that Saints are living testimony of perfectness that should become an example for the believers, it still presupposes the free personal choice by every single man, none excluded. Chaadaev's perspective appears to be strongly elitist, close to the perfect society as delineated by Plato in his Republic.

The second difficulty regards the Eucharist and the Church. On one hand, the Russian philosopher recommends to his literary addressees obedience and simple daily rites as spiritual exercise. On the other, he states that similar observances are suitable for masses, are perfect unless faith does not reach a higher level (it cannot be put aside the fact that Chaadaev belonged to Masonic lodges). Furthermore, the idea of the Church's destiny is perfectly inscribed within the whole historical picture he depicts. This means that single Churches should despoil themselves of their identity in order to melt into just one institution. This theory 
highlights the universal and unifying aspect of the Church that should become one, while undermines the importance of single communities, as well as the interfaith dialogue problem.

The author delineates the Eucharist as a dogma that one day will become the means for the unity of different confessions. This unity is supposed to have a place because of a conscious understanding of the truth, as defined above. For Chaadaev, showing the presence of Christ's body, Eucharist shows the very Example and urges the realization of His doctrine. Considering Christian perspective, Eucharist should also be seen as a moment of communion between the believers. As the great Greek theologian J. Zizioulas explains, this communion is an occasion of thanksgiving for the gift of being by the Other par excellence. The essence of the Eucharistic ethos, he continuous, is the affirmation of the Other and of every Other as a gift to be appreciated and to evoke gratitude. ${ }^{17}$ In other words, Eucharist should first of all be seen as a dialogical communion event. Chaadaev's view of Eucharist points out the dimension of the concrete presence of Christ, while neglecting the fact that this presence is more than a lesson and a model. We could sum up by saying that Chaadaev's perspective is one of a substantial ontology, based on submission and unable to see the need for transformation as intended in the event of transfiguration.

\section{Conclusion}

The ancient Stoics maintained that wise is the man who is able to recognize that the causality chain (heimarmene) is a benevolent providence for him, who accepts to be guided by it and follows their destiny, conscious and joyful. ${ }^{18}$ Despite the attempts made by Chaadaev to underline the human role in history, the force that men can exert in order to change the world and to bring nearer God's Reign, man, as the author

17 See J. Zizioulas, Communion and Otherness. Further Studies in Personhood and the Church, ed. by P. McPartlan, New York 2009, p. 90.

18 See M. Polenz, Die Stoa. Geschichte einer geistingen Bewegung, Goettingen 1959. 
describes him, still resembles a dog chained to a chariot whom those Greek thinkers used to compare mankind. This great Russian philosopher gave a spark to his country that lit a new philosophical fire, but he denied men the most precious and perilous essential trait: their freedom. He insisted in showing the importance of social changes, of ethical improvement, of the renewal his country and people needed, but he tried to inscribe his perception of these needs within the Christian idea regardless of the intimate structure of the human being. Nevertheless, the questions he roused do not become less consistent. Chaadaev is a man of his epoch: his arguments for changes, moved by the love for mankind and for his fatherland, makes his figure one of the biggest humanists of all time.

\section{Bibliography}

Beauchamp P., Parler d'Ecritures Saintes, Paris 1987.

Chaadaev P., The Philosophical Letters Addressed to a Lady, in: The Major Works of Peter

Chaadaev, transl. R. McNally, Notre Dame 1969, p. 18-101.

Polenz M., Die Stoa. Geschichte einer geistingen Bewegung, Goettingen 1959.

Second Vatican Council, Dogmatic Constitution on Divine Revelation Dei Verbum, http://www.vatican.va/archive/hist_councils/ii_vatican_council/documents/vatii_const_19651118_dei-verbum_en.html.

Zenkovsky V. V., A History of Russian Philosophy, vol. 1, transl. G. L. Kline, London 2006. Zizioulas J., Communion and Otherness. Further Studies in Personhood and the Church, ed. by P. McPartlan, New York 2009.

Трубецкой Е., Миросозериание Вл. С. Соловьева, т. 1, Москва 1913. 